\title{
Metabolic complications during HIV-treatment with protease inhibitors in patients from Braşov
}

\author{
Maria-Elena Cocuz ${ }^{*}$, Rodica Silaghi ${ }^{2}$, Bianca Nedelcu², Geta Manea ${ }^{2}$ \\ From The 7th Romanian National HIV/AIDS Congress and The 2nd Central European HIV Forum \\ Sibiu, Romania. 29-31 May 2014
}

Objective: to evaluate the effects of treatment with protease inhibitors on serum level of triglycerides, cholesterol and glycemia in HIV-infected patients, in assessing the need of monitoring patients.

We performed a retrospective study on 25 patients with HIV infection, in evidence of the Infectious Diseases Hospital of Braşov, treated with protease inhibitors in the treatment regimen. We studied the levels of cholesterol, serum triglycerides and blood glucose at the beginning and during treatment with protease inhibitors.

We found increases in serum cholesterol levels in $72 \%$ of patients and in $83.33 \%$ of them were increasing by $50 \%$ from baseline; growth exceeded baseline in $44.45 \%$ of cases. Serum triglycerides have increased to $68 \%$ of patients, with up to $100 \%$ from baseline in $64.5 \%$ of cases and in the rest of the patients the increase was marked, beyond $100 \%$ exceeded normal values in $64.5 \%$ of cases. Blood glucose was maintained at normal levels in $56 \%$ patients and increased in $24 \%$ of cases.

Treatment with protease inhibitors is associated frequently with increased serum levels of cholesterol and triglycerides; hyperglycemia has rarely occurred. Patients treated with protease inhibitors require rigorous monitoring of the metabolism of fats and carbohydrates in order to establish appropriate treatment for early complications that may have occurred.

\section{Authors' details}

${ }^{1}$ Faculty of Medicine, Transilvania University, Braşov, Romania. ${ }^{2}$ Infectious Diseases Hospital, Brașov, Romania.

Published: 29 May 2014

'Faculty of Medicine, Transilvania University, Braşov, Romania

Full list of author information is available at the end of the article
doi:10.1186/1471-2334-14-S4-P32

Cite this article as: Cocuz et al:: Metabolic complications during HIVtreatment with protease inhibitors in patients from Braşov. BMC Infectious Diseases 2014 14(Suppl 4):P32.
Submit your next manuscript to BioMed Central and take full advantage of:

- Convenient online submission

- Thorough peer review

- No space constraints or color figure charges

- Immediate publication on acceptance

- Inclusion in PubMed, CAS, Scopus and Google Scholar

- Research which is freely available for redistribution
() Biomed Central

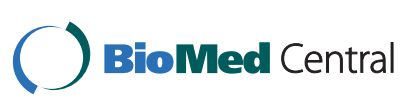

(c) 2014 Cocuz et al; licensee BioMed Central Ltd. This is an Open Access article distributed under the terms of the Creative Commons Attribution License (http://creativecommons.org/licenses/by/4.0), which permits unrestricted use, distribution, and reproduction in any medium, provided the original work is properly cited. The Creative Commons Public Domain Dedication waiver (http:// creativecommons.org/publicdomain/zero/1.0/) applies to the data made available in this article, unless otherwise stated. 